\title{
Work Life Balance in Relation to Well-Being of Religious and Non-Religious Employees
}

\author{
SuboohYusuf ${ }^{1}$, Dr. Kr. Sajid khan ${ }^{2}$
}

\section{ABSTRACT:}

"Work life balance "is a person's control over the conditions in their workplace. The concept of work-family (life) balance has emerged from the acknowledgement that an individual's work-life and personal/family life may exert conflicting demands on each other. A balance between work and life is supposed to exist when there is a proper functioning at work and at home with a minimum of role conflict. "Well-being refers to how people evaluate their lives. According to Diener (1997), these evaluations may be in the form of cognitions or in the form of affect. The cognitive part is an information based appraisal of one's life that is when a person gives conscious evaluative judgments about one's satisfaction with life as a whole. The affective part is a hedonic evaluation guided by emotions and feelings such as frequency with which people experience pleasant/unpleasant moods in reaction to their lives.. Thus the purpose of the research was to explore the relation between work life balance and well-being among employees. Samples were selected through random sampling. 40 employees of different sectors working in Qatar participated in the research. Work life balance scale developed by Hayman(2005) and well-being scale developed by Nishi Zawa (1996). For statistical analysis Pearson correlation was used. Result showed that correlation between work life balance and well-being among non-religious employees was found to be negative and there was positive relation between work life balance and well-being among religious employees.

Keywords: work life balance, well-being, Qatar, teachers.

"Religious" belief is the belief in the reality of the mythological, supernatural, or spiritual aspects of a religion. Religious belief is distinct from religious practice or religious behaviours with some believers not practicing religion and some practitioners not believing religion. Religious beliefs, being derived from ideas that are exclusive to religion, often relate to the existence, characteristics and worship of a deity or deities, divine intervention in the universe and human life, or the deontological explanations for the values and practices centred on the teachings of a spiritual leader or group. "Non-religious" are those who are uninterested in religion or who reject it, this category may include the vague or unaffiliated, those who are only nominally or culturally affiliated to a religious tradition, and the superstitious.

${ }^{1}$ Research scholar, Department of psychology, A.M.U.

${ }^{2}$ Associate Professor, Department of Psychology, Aligarh Muslim University, Aligarh.

(C) 2015 I S Yusuf, S Khan; licensee IJIP. This is an Open Access Research distributed under the terms of the Creative Commons Attribution License (http://creativecommons.org/licenses/by/2.0), which permits unrestricted use, distribution, and reproduction in any Medium, provided the original work is properly cited. 
Work-life balance is the term used to describe those practices at workplace that acknowledge and aim to support the needs of employees in achieving a balance between the demands of their family (life) and work lives. A balance between work and life is supposed to exist when there is a proper functioning at work and at home with a minimum of role conflict. Therefore, the incompatibility between the demands from the work and non-work domain give rise to conflict and consequently, people experience a lack of WLB.

Hyman et al. (2004) observed that organizational pressures, combined with lack of work centrality, result in work intruding into non-work areas of employees' lives. Such intrusions often manifest themselves differently depending on the type of work, extent of autonomy and organizational support.

R. Baral and S. Bhargava (2011) have analyzed that family-friendliness of employers in India have been reflected in various welfare provisions which has been a matter of concern for employers since industrialization. With time, the scope and coverage of such initiatives have broadened and have become more individual growth and family well-being oriented.

Rakesh Yadav, (2011) analyzed that factors such as absence of personal life, physical strains, unscheduled work hours were affecting the attrition from HR perspective which could be minimized by giving extra break to employees who work continuously in night shift for five days, compensating workers with wellness programs and stress busters and aligning employees holidays with the clients' holidays.

Some employees love their work and work long hours by themselves, while others feel that they need to work long hours to demonstrate their commitment to their work. Role overload and role conflict are often predictors of personal life conflict (Carlson and Kacmar 2000).

Work interferes with family life and vice versa(Aldous 1969; Piotrkowski 1979; Staines 1980; Crouter 1984). These iterative processes may have both positive and negative consequences. For most people, work is the means for a better life and for improving the well-being of the family. Organisation expects its employees to work in tandem with its objectives and goals thus contributing positively to its productivity.

Well-being or welfare is a general term for the condition of an individual or group, for example their social, economic, psychological, spiritual or medical state; high well-being means that, in some sense, the individual or group's experience is positive, while low well-being is associated with negative happenings. James McNulty (2012) argues that, "well-being is not determined solely by people's psychological characteristics but instead is determined jointly by the interplay between those characteristics and qualities of people's social environments". Well-being consists of three interrelated components: life satisfaction, pleasant affect, and unpleasant affect. Affect refers to pleasant and unpleasant moods and emotions, whereas life satisfaction refers to a cognitive sense of satisfaction with life (Diener \& Suh, 1997, p. 200).Achieving goals reflects the work of Emerson (1985) and Felce and Perry (1995), who believed that wellbeing stems from individuals' perception of their current situation and their aspirations. 
Shah and Marks consider wellbeing to be more than just happiness. As well as feeling satisfied and happy, well-being means developing as a person, being fulfilled, and making a contribution to the community (2004).

Online interventions appear to help to improve the wellbeing of people with mental health conditions (Espie et al., 2012; Krusche et al., 2012; Morledge et al., 2013; Bowden, 2011).

Van Stolk et al. (2012) highlighted a number of approaches, such as stress recognition schemes, that are effective in improving mental health of employees. Other possible approaches, where the evidence base is still emerging, include interventions such as training line managers to recognize health conditions (Black, 2008; Hassan et al., 2009).

Psychological therapy improves wellbeing of people with mental health problems but there is limited evidence on improvements in employment outcomes. The available evidence from the targeted analysis conducted, which mainly relates to individual-level interventions, indicates that cognitive behavioural approaches can be effective in reducing mental ill-health, presenters and absenteeism (McDaid et al., 2008).

\section{RESEARCH METHODOLOGY}

This exploratory research discussed the relation between work life balance and wellbeing. The data collection is based on a field survey of employees working in Qatar.

$\mathrm{H}_{1}$ - work life balance and well-being are closely related to each other.

$\mathrm{H}_{2}$ - well-being is affected by work life balance.

\section{Sampling and data collection-}

Purposive sampling method was adopted for gathering sample of 40 employees from Qatar.

Participants- Sample of the study consisted of 40 participant's age range was 28-45.they were selected by purposive sampling technique from the different schools of Qatar.

Measurement- Scales used in present study wasWork life balance scale developed by Hayman(2005) and well-being scale developed by Nishi zawa(1996) which were five-point scale.

\section{Statistical tool used-}

The collected data had been analysed by using mean rating scale, correlation. 


\section{RESULT}

Table-1 Correlation between well-being and work-life balance among non-religious employees-

\section{TABLE-1}

\begin{tabular}{|l|c|}
\hline & WORK LIFE BALANCE \\
\hline WELL-BEING NON-RELIGIOUS & -.105 \\
\hline
\end{tabular}

Table-2 Correlation between well-being and work life balance among religious employees-

TABLE-2

\begin{tabular}{|l|l|}
\hline & Work life balance \\
\hline Well-being & .118 \\
\hline
\end{tabular}

According to above tables correlation between work life balance and well-being among nonreligious employees is -.105 which is negative it means that when there is decrease in nonreligious attitude there will be increase in work life balance or vice versa similarly in case of religious employees correlation is which means there is positive relation between work life balance and well-being.

\section{Correlation between well-being and work life balance among employees}

Work life balance and well-being are closely related to each other. Person with positive wellbeing will have good work life balance that is person who is happy can balance his work and personal life happily. Well-being is the most important component of life, person with positive well-being is more satisfied with his life. A lack of work-life balance has been shown to have a negative impact on certain aspects of psychological well-being (Frone, 2000; Higgins et al., 2010). Which means positive well being led to increase in work life balance. Working overtime has been shown to correlate with higher levels of anxiety and depression (Kleppan, Sanne\& Tell, 2008) and with a lack of work-life balance (Dex \& Bond, 2005). Jang (2009) found a positive correlation between work-place flexibility and work-life balance, which was related to positive well-being. Prior research also indicates that positive well-being or a sense of happiness leads to employees working harder (Amabile \& Kramer, 2011). Moreover, it is important that one possess a sense of satisfaction with his or her work and feel supported by his or her employer as it relates to balancing work and personal life. Amabile \& Kramer assert that even though there is an economic advantage for companies to invest in the well-being, truly there is also an ethical obligation to promote well-being. 


\section{REFERENCES}

1. Diener, E., \&Suh, E. (1997). Measuring quality of life: Economic, social, and subjective indicators. Social Indicators Research, $40 \quad$ (1-2), 189-216. http://dx.doi.org/10.1023/A:1006859511756

2. Emerson, E. (1985). Evaluating the impact of deinstitutionalization on the lives of mentally retarded people. American Journal of Mental Deficiency, 90(3), 277-288.

3. Felce, D. \& Perry, J. (1995). Quality of life: Its definition and measurement. Research in Developmental Disabilities, 16(1), 51-74. $\quad$ http://dx.doi.org/10.1016/08914222(94)00028-8.

4. Hyman, J., and J. Summers. (2004). Lacking balance. Personal Review, Vol.33(4), pp. $418-429$.

5. James, W. (1988). Writings 1902-1910. New York: Library of America.

6. R. Baral and S. Bhargava. (2011). HR interventions for work-life balance: evidences from organisations in India. International Journal of Business, Management and Social Sciences, Vol. 2(1), pp. 33-42.

7. RakeshYadav, (2011). Attrition \& HR Initiatives in INDIAN ITES BPO Industry.Research Journal of Social Science \& Management, Vol. (1)2

8. Shah, H., \& Marks, N. (2004). A well-being manifesto for a flourishing society. London: The New Economics Foundation. 